\title{
Tako-tsubo syndrome and atrial fibrillation. New trigger for cardiomyopathy. A clinical case
}

\author{
Elisabetta Demurtas ${ }^{a}$, Rosalba De Sarro ${ }^{a}$, Vito Maurizio Parato ${ }^{b}$, \\ Marianna Gigliotti De Fazioa, Luana Orlandoa , Andrea Giovanni Paratoc, \\ Michele Scarano ${ }^{b}$
}

a Department of Clinical and Experimental Medicine, University of Messina, Messina, Italy

${ }^{b}$ Cardiology Unit of Madonna del Soccorso Hospital, San Benedetto del Tronto, Italy

' School of Medicine, Tor Vergata University, Rome, Italy

\section{ARTICLE INFO}

Article history:

Submitted: 16. 4. 2021

Revised: 27. 8. 2021

Accepted: 30. 8. 2021

Available online: 31.1 .2022
SOUHRN

Takotsubo syndrom (TS) je znám i pod označením stresová kardiomyopatie. Spouštěči TS jsou vnější nebo vnitřní, fyzický nebo psychický stres spojený s katecholaminovou bouř́, nadměrnou sympatickou aktivitou nervového systému nebo s dysfunkcí mikrovaskulatury v prítomnosti systémového zánětu. Popisujeme prípad pacienta s takotsubo kardiomyopatií spojenou s fibrilací síní a s fibromuskulární dysplazií levé předni sestupné větve.

(c) 2022, ČKS

Klíčová slova:

Fibrilace síní

Stresová kardiomyopatie

Takotsubo syndrom

ABSTRACT

Keywords:

Atrial fibrillation

Stress cardiomyopathy

Takotsubo syndrome

Takotsubo syndrome (TS) is well-known to be a stress-induced cardiomyopathy. TS is triggered by external or internal, physical or emotional stress associated with a catecholamine storm, overactivity of sympathetic nerves, or microvascular dysfunction in the setting of systemic inflammation. We report the case of a patient with Takotsubo cardiomyopathy associated with atrial fibrillation and fibromuscular dysplasia of the left anterior descending artery.

\section{Introduction}

TS is a reversible cardiomyopathy characterized by a transient left ventricular disfunction similar to an acute myocardial infarction but in the absence of obstructive coronary artery disease (CAD). Takotsubo syndrome (TS) is described as a pathology with a good prognosis characterized by the presence of a transient left ventricular wall disease without significant culprit obstructive CAD. ${ }^{1-16}$ The "golden standard" for a definitive diagnosis is invasive coronary angiography and ventriculography, with an integrated multi-imaging approach, such as echocardiography, first-line non-invasive technique, and cardiac magnetic resonance (CMR), in order to discriminate TS from other acute cardiac syndromes with troponin elevation and ventricular disfunction. ${ }^{16-19}$ Important hallmarks of TS are a relatively small increase in T/I troponin, the left ventricle "apical ballooning" (wall motion diskinesis characterized by apical akinesis and basal hyperkinesis) at echocardiography and ventriculography associated with normal epicardial coronary vessels at angiography. $3,7,14,19-22$ In addition there may be catecholamines (epinephrine, norepinephrine, and dopamine) and NT-proBNP elevation.

\section{Case presentation}

A 73-year-old woman presented with sudden onset chest pain and dyspnea about six hours after a rapid atrial fibrillation presenting with palpitations. In her history there was arterial hypertension treated with ACE inhibitors and dyslipidemia treated with statins for 10 years. The

Address: Michele Scarano, MD, Cardiology Unit, Emergency Dept, Hospital "Madonna del Soccorso", Via Silvio Pellico n. 32, 63039 San Benedetto del Tronto, Ascoli Piceno, Italy, e-mail: michelescarano1978@gmail.com DOI: 10.33678/cor.2021.107 


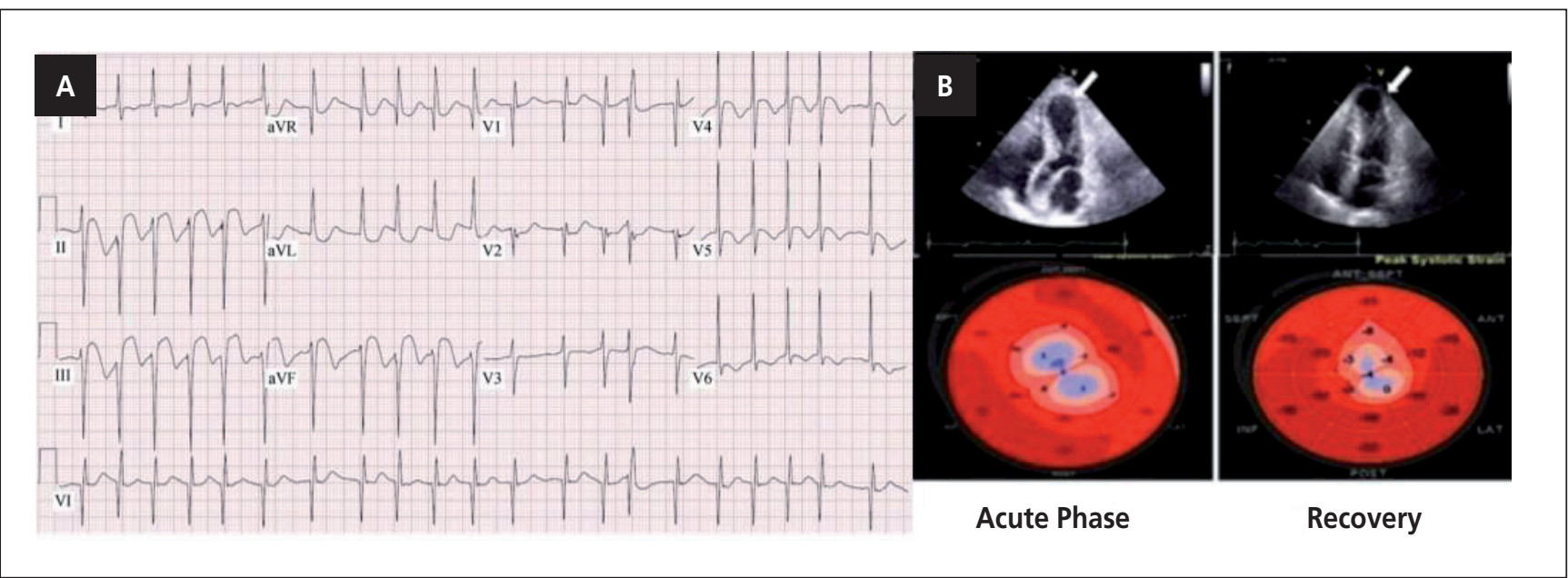

Fig. 1 - (A) ECG: Atrial fibrillation; inferior wall ST segment elevation, and negative T waves in lateral leads (suggestive of inferior-lateral myocardial infarction "STEMI"). (B) TTE revealed apical ballooning, also evaluated with global longitudinal strain (GLS) which is reduced in the recovery phase.

electrocardiography indicated "high-rate atrial fibrillation with ST segment elevation in inferior leads and negative $T$ waves in lateral leads, suggestive of inferior-lateral myocardial infarction, and QT prolongation", "inferior wall ST segment elevation myocardial infarction", T wave inversion in apical wall and QT prolongation (Fig. 1A). The clinical course included a severe pulmonary edema complicated by cardiogenic shock..$^{1,7,8,19-21}$ Coronary angiography ruled out obstructive lesion in the major coronary arteries, but revealed fibromuscular dysplasia of the distal tract of the left anterior descending artery. The ventriculography showed remarkable ventricular dilation. Trans-thoracic echocardiography (TTE) revealed a left ventricle (LV) apical ballooning with hyperkinetic basal segments also evaluated and confirmed with global longitudinal strain (GLS, Fig. 1B). LV ejection fraction (EF) evaluated by echocardiography was $35 \%$ (in old TTE, one year ago, EF 50\%). In the acute phase she was treated with beta-blockers, furosemide and amiodarone i.v. without clinical improvement; therefore we decided to perform electrical cardioversion which restored sinus rhythm. Furthermore, during the hospitalization and immediately after the acute phase she was treated with her usual therapy for hypertension (ACE inhibitors) and dyslipidemia.

Pulmonary congestion disappeared and the patient was dismissed from hospital and got back to her normal life with her past home therapy. Amiodarone has not been prescribed as home therapy due to the presence of QT prolongation on the ECG. Her LV systolic function normalized within one week (EF 50\%), except for a residual inferior-apical hypokinesis. She had no more symptoms.

\section{Discussion}

This case focuses on the relationship between TS, atrial fibrillation (AF) and coronary fibromuscular dysplasia. In the medical literature, Stiermaier et al. ${ }^{23}$ report that in TS patients, atrial fibrillation is frequent and associated with increased long-term mortality rates. A meta-analysis pro- duced by Prasitlumkun et al. ${ }^{24}$ suggests that the presence of $A F$ is a prognostic factor for all-cause mortality among patients with TS compared to those lacking it. However, there is no case reported in literature that could define $\mathrm{AF}$ as a trigger event. There are several cases of TS associated with coronary anomalies, ${ }^{25}$ but none of these have atrial fibrillation as a trigger. Even though we don't know the exact etiology of TS, the onset is preceded by a trigger event in the majority of patients (70-80\%). Stressor trigger is identified in about $70 \%$ of cases. The typical patient with Takotsubo syndrome is a post-menopausal women who has experienced severe, unexpected emotional or physical stress. A genetic predisposition has been suggested related to polymorphisms in relevant candidate

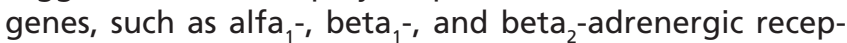
tors, GRK5, and estrogen receptors. During a paroxysmal atrial fibrillation, psychological stress and/or physical pain can stimulate central/autonomic nervous systems, and increase bioavailability of cortisol and circulating catecholamines, which may affect the myocardium. So, from a pathophysiological point of view it may be a convergence between the classical stressor events and the AF: they both provoke the release of catecholamines which appear to have a central role in the development of Takotsubo syndrome. Also the presence of fibromuscular dysplasia of left anterior descending coronary during atrial fibrillation could result in coronary vasospasm cause circumscribed left ventricular contraction abnormalities found in TS.

\section{Acknowledgements}

None.

\section{Conflict of interests}

None.

\section{References}

1. Bossone E, Savarese G, Ferrara F et al. Takotsubo cardiomyopathy: overview. Heart Fail Clin 2013;9:249-266.

2. Y-Hassan S, Tornvall P. Epidemiology, pathogenesis, and management of takotsubo syndrome. Clin Auton Res 2018;28:53-65. 
3. Bitto R, Casale M, Morabito $\mathrm{C}$, et al. Takotsubo Cardiomyopathy: A Benign Condition or a Bad Omen? Angiology 2018;69:100-102.

4. Stelmach $Z$, loniță OR, Buděšínský $T$, et al. Reverse Takotsubo syndrome, a rare form of "Broken Heart" syndrome. Cor Vasa 2020;62:486-491.

5. Azouzi A, Omri M, Kraiem H, et al. latrogenic epinephrine-induced Takotsubo cardiomyopathy in beta-blocker poisoning: case report. Cor Vasa 2019;61:e319-e322.

6. Casale M, Quattrocchi S, Bitto R, et al. Cardiac implantable devices and takotsubo syndrome. A rare but potential eventuality. Cor Vasa 2018;60:e500-e502.

7. Hůlka J, Soukup J. Rupture of free wall of left ventricle in a patient with takotsubo cardiomyopathy. Cor Vasa 2018;60:e503-e507.

8. Patanè $S$, Marte $F$, Sturiale $M$, et al. Atrial flutter, ventricular tachycardia and changing axis deviation associated with scleroderma. Int J Cardiol 2011;153:e25-e28.

9. Kadlečková P, Roubíček T, Polášek R. Paraganglioma-induced takotsubo cardiomyopathy. Cor Vasa 2020;62:89-93.

10. Tulino V, Cacace $C$, Tulino $D$, et al. Clinical variants in Ebstein's anomaly. Int J Cardiol 2013;168:4969-4970.

11. Mutluer FO, Madonna R, Cevik C, et al. Biventricular Takotsubo syndrome in a patient with coronary abnormality and end-stage renal disease. Cor Vasa 2013;55:e277-e280.

12. Imbalzano $E$, Dattilo $G$, Scarpelli $M$, et al. Left coronary artery fistula to right ventricle complicated heart failure in a patient on hemodialysis. Intern Emerg Med 2013;8:765-766.

13. Eremiášová $L$, Marek J, Paleček $T$, et al. Takotsubo cardiomyopathy in a patient with essential thrombocythemia treated with anagrelide: Case report. Cor Vasa 2018;60:e327e330.

14. Dattilo G, Carerj S, Lamari A, et al. The chance finding at multislice computed tomography coronary angiography of myocardial bridging. Int J Cardiol 2012;154:e21-e23.
15. Patanè $S$, Marte $F$, Dattilo $G$, et al. Changing axis deviation during atrial fibrillation. Int J Cardiol 2012;154:e1-e3.

16. Pavlovič J, Hlaváček $K$, Feuereisl $R$, et al. Role of a dynamic LVOT obstruction in the pathogenesis of takotsubo syndrome. Cor Vasa 2010;52:695-699.

17. De Gregorio C Dattilo G, Casale M, et al. Left Atrial Morphology, Size and Function in Patients With Transthyretin Cardiac Amyloidosis and Primary Hypertrophic Cardiomyopathy - Comparative Strain Imaging Study. Circ 2016;80:1830-1837.

18. Imbalzano E, Saitta A, Lamari A, et al. Echo-Doppler evaluation of recent onset chronic venous insufficiency in elderly patients: does the heart have a role? Recenti Prog Med 2013;104:569-573.

19. Zajíček $P$, Wiesner $R$, Prodělal $P$, et al. Takotsubo cardiomyopathy as an option in the differential diagnosis in transient left ventricular dysfunction. Cor Vasa 2007;49:318-321.

20. Dattilo G, Imbalzano E, Lamari A, et al. Ischemic heart disease and early diagnosis. Study on the predictive value of 2D strain. Int J Cardiol 2016;215:150-156.

21. Casale M, Correale M, Laterra G, et al. Effects of Sacubitril/ Valsartan in Patients with High Arrhythmic Risk and an ICD: A Longitudinal Study. Clin Drug Investig 2021;41:169-176.

22. Kaučák V, Mrózek J, Černý P. A case report of transient left ventricular apical ballooning. Cor Vasa 2007;49:378-382.

23. Stiermaier T, Eitel I, Eitel C. Atrial arrhythmias in Takotsubo syndrome: is inflammation the missing link? Europace 2019;21:184-185.

24. Prasitlumkum N, Kittipibul V, Limpruttidham N, et al. The presence of atrial fibrillation in Takotsubo cardiomyopathy is predictive of mortality: Systematic review and meta-analysis. Ann Noninvasive Electrocardiol 2019;24:e12566.

25. Cheng Y, Lu C, Liu K. Multi-modality imaging evaluation of recurrent Tako-tsubo syndrome in a patient with coronary artery fibromuscular dysplasia. Cardiovasc Ultrasound 2017;15:26. 